This article was downloaded by:[National University of Ireland Maynooth]

On: 27 March 2008

Access Details: [subscription number 769440816]

Publisher: Informa Healthcare

Informa Ltd Registered in England and Wales Registered Number: 1072954

Registered office: Mortimer House, 37-41 Mortimer Street, London W1T 3JH, UK

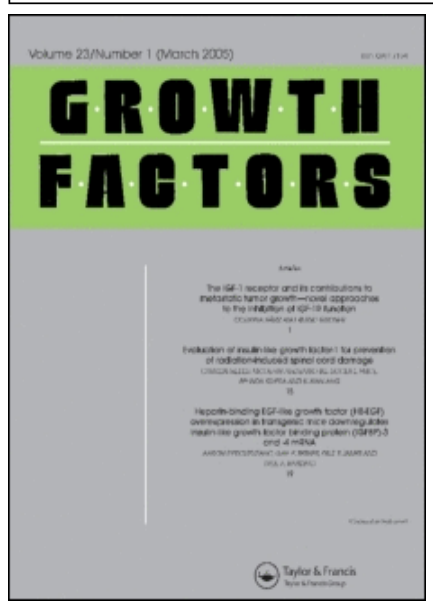

\title{
Growth Factors
}

Publication details, including instructions for authors and subscription information: http://www.informaworld.com/smpp/title content=t713642964

BMP4 induces an epithelial-mesenchymal transition-like response in adult airway epithelial cells

Emer L. Molloy ${ }^{a}$; Aine Adams ${ }^{\text {a; }}$ J. Bernadette Moore ${ }^{a}$; JOANNE C. Masterson ${ }^{a}$; Laura Madrigal-Estebas ${ }^{a}$; Bernard P. Mahon ${ }^{\text {a }}$; Shirley O'Dea ${ }^{a}$

a Institute of Immunology, Biology Department, National University of Ireland,

Maynooth, Ireland

First Published on: 11 March 2008

To cite this Article: Molloy, Emer L., Adams, Aine, Moore, J. Bernadette,

Masterson, JOANNE C., Madrigal-Estebas, Laura, Mahon, Bernard P. and O'Dea,

Shirley (2008) 'BMP4 induces an epithelial-mesenchymal transition-like response in

adult airway epithelial cells', Growth Factors, 26:1, 12 - 22

To link to this article: DOI: $10.1080 / 08977190801987166$

URL: http://dx.doi.org/10.1080/08977190801987166

\section{PLEASE SCROLL DOWN FOR ARTICLE}

Full terms and conditions of use: http://www.informaworld.com/terms-and-conditions-of-access.pdf

This article maybe used for research, teaching and private study purposes. Any substantial or systematic reproduction, re-distribution, re-selling, loan or sub-licensing, systematic supply or distribution in any form to anyone is expressly forbidden.

The publisher does not give any warranty express or implied or make any representation that the contents will be complete or accurate or up to date. The accuracy of any instructions, formulae and drug doses should be independently verified with primary sources. The publisher shall not be liable for any loss, actions, claims, proceedings, demand or costs or damages whatsoever or howsoever caused arising directly or indirectly in connection with or arising out of the use of this material. 


\title{
BMP4 induces an epithelial-mesenchymal transition-like response in adult airway epithelial cells
}

\author{
EMER L. MOLLOY, AINE ADAMS, J. BERNADETTE MOORE, JOANNE C. MASTERSON, \\ LAURA MADRIGAL-ESTEBAS, BERNARD P. MAHON, \& SHIRLEY O'DEA \\ Institute of Immunology, Biology Department, National University of Ireland, Maynooth, Ireland
}

(Received 30 fuly 2007; revised 18 fanuary 2008; accepted 22 fanuary 2008)

\begin{abstract}
Bone morphogenetic proteins (BMPs) are critical morphogens and play key roles in epithelial-mesenchymal transitions (EMTs) during embryogenesis. BMP4 is required for early mesoderm formation and also regulates morphogenesis and epithelial cell differentiation in developing lungs. While, BMP signalling pathways are activated during lung inflammation in adult mice, the role of BMPs in adult lungs remains unclear. We hypothesised that BMPs are involved in remodelling processes in adult lungs and investigated effects of BMP 4 on airway epithelial cells. BEAS-2B cell growth decreased in the presence of BMP4. Cells acquired a mesenchymal-like morphology with downregulation of adherens junction proteins and increased cell motility. Changes in extracellular matrix-related gene expression occurred with BMP4 treatment including upregulation of collagens, fibronectin and tenascin C. We conclude that the activity of BMP4 in EMT during development is recapitulated in adult airway epithelial cells and suggest that this activity may contribute to inflammation and fibrosis in vivo.
\end{abstract}

Keywords: BMP, EMT, ECM, E-cadherin, airway

\section{Introduction}

Epithelial and mesenchymal cells represent distinct cell lineages with characteristic gene expression profiles that confer specific features to each tissue type. Respective characteristic profiles of cell adhesion and cytoskeletal proteins enable epithelial cells to form tightly connected, organised sheets while mesenchymal cells are capable of motility and invasion. Epithelialmesenchyme transition (EMT) is a process whereby epithelial cells lose their epithelial features and acquire mesenchymal characteristics (Lee et al. 2006) and occurs during morphogenesis (Shook and Keller 2003) and also during carcinogenesis and fibrosis in adult tissues (Thiery 2003). During EMT, epithelial cells alter their phenotype, downregulating expression of specific cell adhesion molecules and cytokeratins and inducing expression of mesenchymal-specific proteins such as collagens, fibronectin, $\alpha$-smooth muscle actin and matrix degrading enzymes (Kalluri and Neilson 2003). Altered protein expression is accompanied by a switch in morphology as cells acquire a mesenchymal-like appearance and grow in a more scattered manner.

Induction of EMT occurs in response to cytokines such as transforming growth factor beta 1 (TGF- $\beta 1$ ), fibroblast growth factor 2 (FGF-2), hepatocyte growth factor (HGF) and epidermal growth factor (EGF) (Savanger 2001). TGF- $\beta 1$ in particular is considered to be a prototypic inducer of EMT and regulates this process both during development and in adult disease states (Zavadil and Bottinger 2005; Willis and Borok 2007). Repression of E-cadherin expression is a key step in the EMT process (Burdsal et al. 1991). Growth factor signalling pathways have been shown to modulate activity of transcription

Correspondence: S. O'Dea, Institute of Immunology, Biology Department, National University of Ireland, Maynooth, Ireland. Tel: +3531 708 6117. Fax: +3531708 6337. E-mail: shirley.odea@nuim.ie 
factors that repress E-cadherin gene expression (Thiery 2003). SNAI1, SNAI2, ZEB1, ZEB2 and Twist are transcriptional repressors of E-cadherin and other epithelial genes (Peinado et al. 2007). Several of these factors also induce expression of mesenchymal genes and so are regarded as the molecular effectors of EMT. SNAI1 is downstream of TGF- $\beta 1$ and FGF signalling pathways (Thiery 2003; Zavadil and Bottinger 2005) and regulates induction of EMT in response to these growth factors.

Bone morphogenetic proteins (BMPs) form a highly conserved group within the transforming growth factor $\beta$ (TGF- $\beta$ ) superfamily of secreted growth factors. To date, more than $20 \mathrm{BMPs}$ have been described (Chen et al. 2004). During development, BMPs regulate a variety of processes including left-right asymmetry, mesodermal patterning and organogenesis (Herpin and Cunningham 2007). In the adult, the role of BMPs in bone formation has been widely investigated. BMPs are also involved in proliferation, differentiation, apoptosis and regeneration processes in other adult tissues (Simic and Vukicevic 2005; Abe 2006).

BMP2 and BMP4 are $92 \%$ identical (Wozney 1992) and are the mammalian homologues of Drosophila decapentaplegic peptide (Dpp) (Wozney 1989). Both are critical to a variety of developmental processes including EMT aspects of morphogenesis (Chen et al. 2004). BMP4 drives early mesoderm formation (Winnier et al. 1995) while BMP2 is required for EMT during heart morphogenesis (Okagawa et al. 2007). Homozygous deletions of BMP2 and BMP4 in mice are embryonic lethal due to abnormal heart development and a failure of mesoderm formation, respectively (Winnier et al. 1995; Zhang and Evans 1996). In the developing lung, BMP4 regulates branching morphogenesis and modulates proximalto-distal differentiation of ciliated and secretory airway epithelial cells although the mechanism involved is unknown (Weaver et al. 1999). A role for BMP2 in lung development has not yet been established. BMP4 induces EMT during neural crest formation via upregulation of SNAI2 expression (Sakai et al. 2006).

BMP signals are transduced via hetero-oligomeric types I and II receptors (Ruberte et al. 1995; Nohe et al. 2002). Following ligand binding, BMPR-II transphosphorylates type I receptors which in turn recruit and phosphorylate the receptor-regulated Smads (R-Smads) 1,5 and/or 8 (Attisano and Wrana 2000). Activated R-Smads form heteromeric complexes with Smad4 which is also involved in TGF- $\beta$ and activin signalling pathways. Heteromeric Smad complexes translocate to the nucleus where they act as transcriptional co-modulators of specific target genes. In addition to the canonical Smad signalling pathway, BMP receptor-mediated signalling also interacts with p38 mitogen-activated protein kinase,
Toll and Notch signalling pathways (Herpin and Cunningham 2007). Relatively few BMP target genes have thus far been identified in mammalian cells (Frontelo et al. 2004; Miyazono et al. 2005; Perk et al. 2005). Notably with regard to EMT, SNAI1 is one such target gene (Miyazono et al. 2005).

It has been proposed that signals critical to lung morphogenesis, such as BMP4, are also likely to be involved in regeneration and disease processes in adult lungs (Bellusci et al. 1996; Warburton and Bellusci 2004). BMP2 is overexpressed in human lung carcinomas (Langenfeld et al. 2005). BMP4 has been reported to induce senescence in A549 cells in vitro (Buckley et al. 2004) and BMP pathway activation and upregulation of BMP4 occurs in allergen-induced inflammation in mouse lungs in vivo (Rosendahl et al. 2002). However, despite being members of the TGF- $\beta$ superfamily, the role of BMPs in adult lungs has received little attention to date and remains unknown. TGF- $\beta$ has recently been shown to induce EMT in alveolar epithelial cells in vitro and in vivo indicating a possible novel mechanism for lung fibrosis (Willis and Borok 2007). BMP4 induces EMT in adult ovarian, mammary and pancreatic cancer cells (Montesano 2007; Hamada et al. 2007; Theriault et al. 2007). In this study, we investigated the effects of BMP4 on adult airway epithelial cells using the BEAS2B cell line. BMP4 inhibited proliferation and induced epithelial-mesenchymal transition (EMT)like changes in BEAS-2B cells. Our study reveals that aspects of the EMT-inducing activities of BMP4 during development are recapitulated in adult lung cells and indicates that inappropriate BMP-mediated EMT in vivo could directly contribute to lung inflammation and fibrosis.

\section{Materials and methods}

\section{Cell culture}

BEAS-2B cells were obtained from the American Type Culture Collection. Cells were routinely cultured in a 1:1 mixture of DMEM:Hams-F12 medium supplemented with $5 \%$ fetal bovine serum (Gibco, Glasgow, UK) and $2 \mathrm{mM} \mathrm{L-glutamine} \mathrm{(Gibco).} \mathrm{Cells}$ were maintained at $37^{\circ} \mathrm{C}$ in a humidified atmosphere of $5 \% \mathrm{CO}_{2}$. Experiments were carried out within five passage numbers of each other.

\section{Treatment of BEAS- $2 B$ cells with BMP4}

Cells were harvested at $>80 \%$ confluency and seeded in DMEM supplemented with $10 \%$ FBS and $2 \mathrm{mM}$ L-glutamine at densities of $4 \times 10^{3}$ cells per well of a 24 -well tissue culture plate, $5 \times 10^{4}$ cells per $25 \mathrm{~cm}^{2}$ tissue culture flask or $1.5 \times 10^{5}$ cells per $75 \mathrm{~cm}^{2}$ flask depending on the experiment. After overnight attachment, cells were rinsed three times with basal Hams-F12 
medium and $100 \mathrm{ng} / \mathrm{ml} \mathrm{BMP4}$ (R\&D Systems, Minneapolis, USA) was added in defined serum-free medium (1:1 Hams-F12:M199 medium supplemented with $2 \mathrm{mM}$ L-glutamine (Gibco), $100 \mathrm{U} / \mathrm{ml}$ penicillin (Gibco), $100 \mu \mathrm{g} / \mathrm{ml}$ streptomycin (Gibco), $100 \mathrm{U} / \mathrm{ml}$ insulin-transferin-selenium (Gibco), $100 \mathrm{ng} / \mathrm{ml}$ hydrocortisone (Sigma-Aldrich, Dublin, Ireland) and $10 \mathrm{ng} / \mathrm{ml}$ epidermal growth factor (R\&D Systems).

\section{Cell counts}

Cell numbers and viability were determined by ethidium bromide/acridine orange staining and cell counting using a haemocytometer. Adherent cells and suspension cells were harvested by trypsinisation and centrifugation respectively and total viable and nonviable populations were determined.

\section{Cell motility assay}

Cells were grown to confluency on glass coverslips $(25 \mathrm{~mm})$ in six-well tissue culture plates and were wounded with a sterile $200-\mu l$ pipette tip to generate a cell-free area of approximately $500 \mu \mathrm{m}$ in width. Cell debris was removed by washing with PBS and cells were cultured in defined serum-free medium for $24 \mathrm{~h}$. Medium was replaced with fresh defined serum-free medium with or without BMP4 $(100 \mathrm{ng} / \mathrm{ml})$ in triplicate wells. At 4,8 and $17 \mathrm{~h}$, cells were fixed with methanol for $5 \mathrm{~min}$, air-dried and stained with crystal violet solution (Sigma). Phase-contrast photomicrographs of five fields of view per scrape were acquired using an inverted microscope equipped with a digital camera (Olympus C-310). Cells in each field of view were counted and the average number of cells present in each scrape with each treatment was determined.

\section{Immunofluorescence}

At appropriate timepoints, cells were rinsed with PBS and fixed at $-20^{\circ} \mathrm{C}$ for $5 \mathrm{~min}$ with pre-chilled methanol. Phosphorylated Smad1/5/8 antibody (New England Bio Labs, Beverly, MA, USA) was incubated overnight at $4^{\circ} \mathrm{C}$ followed by a $30 \mathrm{~min}$ at room temperature incubation with goat anti-rabbit Alexa Fluor ${ }^{\circledR}$ 488-labelled secondary antibody (Molecular Probes, Invitrogen, Paisley, UK). Cells were counterstained using DAPI nuclear stain (Sigma). Fluorescence was examined using an Olmypus IX81 fluorescent microscope, where camera and microscope settings (exposure time, brightness and light intensity) were kept constant across treatments (Olympus Life and Material Science Europe, Hamburg, Germany). Cells omitting primary antibody were included as a control.

\section{Western blotting}

Cells were scraped in ice-cold PBS and pellets were lysed in radioimmunoprecipitation assay (RIPA) buffer (Sigma). Protein (10 $\mu$ g per lane) was electrophoresed through $10 \%$ polyacrylamide gels and blotted onto nitrocellulose membrane. Blots were probed with primary antibodies for either $1 \mathrm{~h}$ at room temperature or overnight at $4^{\circ} \mathrm{C}$ and incubated with horseradish peroxidase-linked secondary antibodies for $1 \mathrm{~h}$ at room temperature. Visualisation was performed using an ECL detection system (Amersham, Little Chalfont, UK). Antibodies were E-cadherin (clone-36), $\alpha$-catenin (clone-5), $\beta$-catenin (clone-14) and $\gamma$-catenin (clone-15) (Becton-Dickinson), cytokeratin 8 (clone M20) (Sigma) and cytokeratin 18 (Clone CY-90) (Sigma). Quantification was carried out by comparative densitometry with actin (20-33) (Sigma) using QuantityOne ${ }^{\circledR}$ software version 4.4.1 (Bio-Rad Laboratories Inc., Hertfordshire, UK).

\section{Semi-quantitative PCR}

Total RNA was isolated using TRIZOL Reagent (Invitrogen). After quantity/quality confirmation, $1 \mu \mathrm{g}$ was DNase treated (Sigma) and reverse transcribed with $200 \mathrm{U}$ SuperScript ${ }^{\mathrm{TM}}$ III (Invitrogen). PCR products were visualised on ethidium bromide stained gels and semi-quantified using the QuantityOne software version 4.4.1 (Bio-Rad). Values obtained were normalised using housekeeping gene, glyceraldehyde-3-phosphate (GAPDH). Target transcripts were amplified using $300 \mathrm{nM}$ primer (note: two independent primer sets were used for COL1A1, COL1A2 and Vimentin) (Table I).

\section{PCR arrays}

For PCR array experiments, total RNA was isolated from BEAS-2B cells using RNeasy ${ }^{\mathrm{TM}}$ and QIAshredder columns (QIAGEN Ltd., West Sussex, UK) according to manufacturer's directions and included the on-column DNase digestion step. RNA quantity and quality was confirmed both by ethidium bromide (Sigma) staining for ribosomal RNA band integrity and UV-Vis spectrophotometry. Only high quality RNA (A260:A280 and A260:A230 ratios greater than 2.0) was used.

$\mathrm{RT}^{2}$ Profiler $^{\mathrm{TM}}$ PCR arrays for housekeeping genes and ECM-related genes, cDNA synthesis reagents and $\mathrm{RT}^{2} \mathrm{SYBR}^{\mathrm{TM}}$ green PCR master mixes were all purchased from SuperArray Bioscience Corporation (Maryland, USA) and protocols were followed precisely. In brief, for first strand cDNA synthesis, $1 \mu \mathrm{g}$ total RNA was incubated with random hexamers and oligodT primers at $70^{\circ} \mathrm{C}$ for $3 \mathrm{~min}$, then at $37^{\circ} \mathrm{C}$ for $10 \mathrm{~min}$ to permit annealing. An equal volume of RT 
Table I. RT-PCR primer sets.

\begin{tabular}{|c|c|c|}
\hline Primer & Sense & Antisense \\
\hline SNAI1 & 5'-CCAGAGTTTACCTTCCAGCA-3' & 5'-CAGAGTCCCAGATGAGCATT-3' \\
\hline SNAI2 & 5'-CCTGGTCAAGAAGCATTTCA-3' & 5'-CCTTGGAGGAGGTGTCAGAT-3' \\
\hline SNAI3 & 5'-ACACAGGGGAGAAGCCCTAT-3' & 5'-ACATGCGGGAGAAGGTCT-3' \\
\hline ZEB1 & 5'-CACCCTTGAAAGTGATCCAG-3' & 5'-TCTTCCGCATTTTCTTTTTG-3' \\
\hline Twist & 5'-CTTCTCGGTCTGGAGGATG-3' & 5'-TCСАТTTTСТССТTСТCTGG-3' \\
\hline Desmin & 5'-AACСТTCTCTGCССТСAACT-3' & 5'-GATCATCACCGTCTTCTTGG-3' \\
\hline $\mathrm{N}$-cadherin & 5'-TGTTTTGGACCGAGAATCAC-3' & 5'-TAACACTTGAGGGGCATTGT-3' \\
\hline Set 1 COL1A 1 & 5'-CTGGTGCTAAAGGTGCCAAT-3' & 5'-СTCСTCGCTTTCСTTCСТCT-3' \\
\hline Set 2 COL1A1 & 5'-GTGCTACTGGTTTCCCTGGT-3' & 5'-ACСTTTGCCACСTTCTTTG-3' \\
\hline Set 1 COL1A2 & $5^{\prime}$-GAAAACATCCCAGCCAAGAA-3' & 5'-GCCAGTCTCCTCATCCATGT-3' \\
\hline Set 2 COL1A2 & $5^{\prime}$-CCGAACTGGAGAAGTAGGTG-3' & 5'-AGGGAGACCCAGAATACCAG-3' \\
\hline Fibronectin & $5^{\prime}$-GGAAAAGGAGAATGGACCTG-3' & $5^{\prime}$-CTTCTCCCAGGCAAGTACAA- $3^{\prime}$ \\
\hline Set 1 vimentin & 5'-CGAAAACACCCTGCAATCTT-3' & 5'-GTGAGGTCAGGCTTGGAAAC-3' \\
\hline Set 2 vimentin & 5'-AACCTGACCGAGGACATCATG-3' & 5'-TTCTCGGCTTCCTCTCTCTGAA-3' \\
\hline$\alpha$-SMA & 5'-ACTACTGCCGAGCGTGAGAT-3' & $5^{\prime}$-ATAGGTGGTTTCGTGGATGC-3' \\
\hline Keratin 18 & $5^{\prime}$-GGAGCACTTGGAGAAGAAGG-3' & 5'-GGGCATTGTCCACAGTATTT-3' \\
\hline GAPDH & 5'-CTGCACCACCAACTGCTTAG-3' & 5'-CCAGGAAATGAGCTTGACAAA-3' \\
\hline
\end{tabular}

mix was then added, incubated at $37^{\circ} \mathrm{C}$ for $1 \mathrm{~h}$ and then heated to $95^{\circ} \mathrm{C}$ for $5 \mathrm{~min}$. The cDNA was then diluted with $4 \mathrm{vol}$ of $\mathrm{ddH}_{2} \mathrm{O}$ to a final volume of $100 \mu \mathrm{l}$. Ninety-eight microlitres of this was combined with 2X SYBRâ green PCR master mix and $\mathrm{ddH}_{2} \mathrm{O}$, then aliquoted to the PCR array. No RT and no template controls were included on all plates. PCR was performed on a DNA Engine Opticon ${ }^{\circledR}$ (BioRad). After an initial 10 min heat step at $95^{\circ} \mathrm{C}, 40$ cycles of: $15 \mathrm{~s}$ at $95^{\circ} \mathrm{C}, 40 \mathrm{~s}$ at $55^{\circ} \mathrm{C}$ and $30 \mathrm{~s}$ at $72^{\circ} \mathrm{C}$ were performed.

Data were exported to Microsoft Excel and fold changes in gene expression were calculated by the $2\left(-\Delta \Delta C_{\mathrm{t}}\right)$ method. Average cycle threshold $\left(C_{\mathrm{t}}\right)$ was calculated across biological replicates $(n=3$, independent passages) for each gene and the $\Delta C_{\mathrm{t}}$ was calculated by subtraction of the average $C_{\mathrm{t}}$ of five housekeeping genes.

\section{Quantitative PCR}

Total RNA was isolated using TRIZOL Reagent (Invitrogen). After quantity/quality conformation, $1 \mu \mathrm{g}$ was DNase treated (Sigma) and reverse transcribed with $200 \mathrm{U}^{\text {SuperScript }}{ }^{\mathrm{TM}}$ III (Invitrogen). QPCR was performed using the Quantitectâ SYBRâ Green mastermix (Qiagen) and Quantitectâ primer assays (Qiagen) were used for GAPDH, COL5A1, TGFBI, MMP2 and ZEB2. CDH1 primers were designed in house [sense: $5^{\prime}$-TCTGATTCTGCTGCTCTTGC- $3^{\prime}$ and antisense 5'-AAAGTCCTGGTCCTCTTCTCC- $3^{\prime}$ ] and used at $300 \mathrm{nM}$ each. All assays were performed on the DNA Engine Opticon ${ }^{\circledR}$ and relative quantitation was computed from a 4-5 log range standard curve generated from 1:10 serial dilutions of cDNA. Samples $(n=3)$ were run in triplicate and GAPDH was used as the endogenous control.

\section{Results}

$B M P$ pathway activation in $B E A S-2 B$ cells in response to $B M P 4$

To determine whether BEAS-2B cells contain a BMP signalling pathway, the expression, activation and localisation of Smad proteins was examined. The P-Smad antibody used here cross-reacts with the phosphorylated forms of Smads 1, 5 and 8. Smad $1 / 5 / 8$ phosphorylation was detected in BEAS-2B cells cultured in control defined serum-free medium without BMP4 treatment at both the 20 min and day 6 time points indicating a basal level of pathway activity in these cells (Figure 1). Following stimulation with BMP4, an increase in levels of phosphorylated Smad 1/5/8 was evident by immunofluorescence and Western blotting (Figure 1). An increase in nuclear localisation of phosphorylated Smad 1/5/8 was also apparent (Figure 1a). Thus, BEAS-2B cells are capable of responding to BMP4 ligands and increased pathway activity is maintained for at least 6 days following introduction of ligand.

$B M P 4$ induces a fibroblast-like morphology in BEAS-2B cells

The BEAS-2B cell line was originally derived from normal bronchial epithelium (Reddel et al. 1988). Cells were routinely cultured in the presence of fetal bovine serum. Cells transferred to control defined serum-free medium for up to 10 days retained characteristic epithelial cell morphologies (Figure 2a, c, e). In contrast, after 3 days of culture in defined serum-free medium containing $100 \mathrm{ng} / \mathrm{ml} \mathrm{BMP} 4$, an alteration in BEAS-2B cell morphology was apparent in areas where colonies had formed (Figure 2b). In these areas, cells appeared more elongated and angular and had reduced cell-cell contacts compared 
(a)
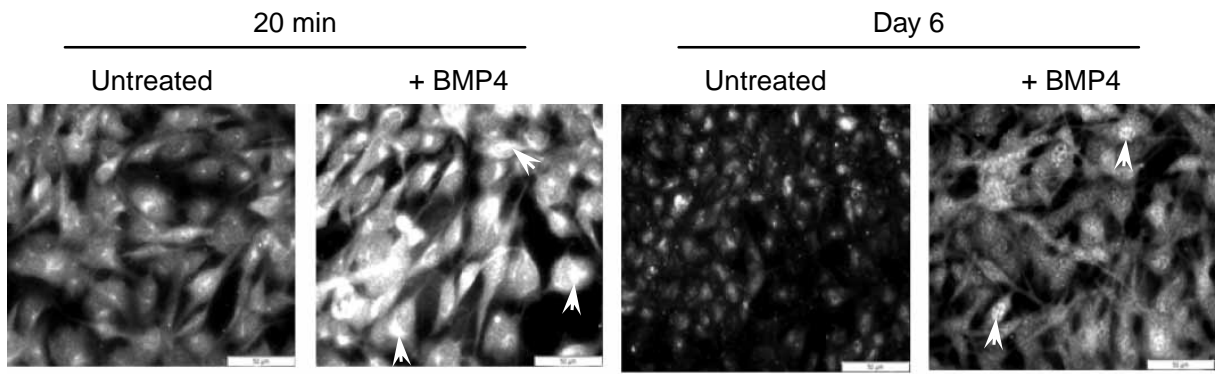

(b)
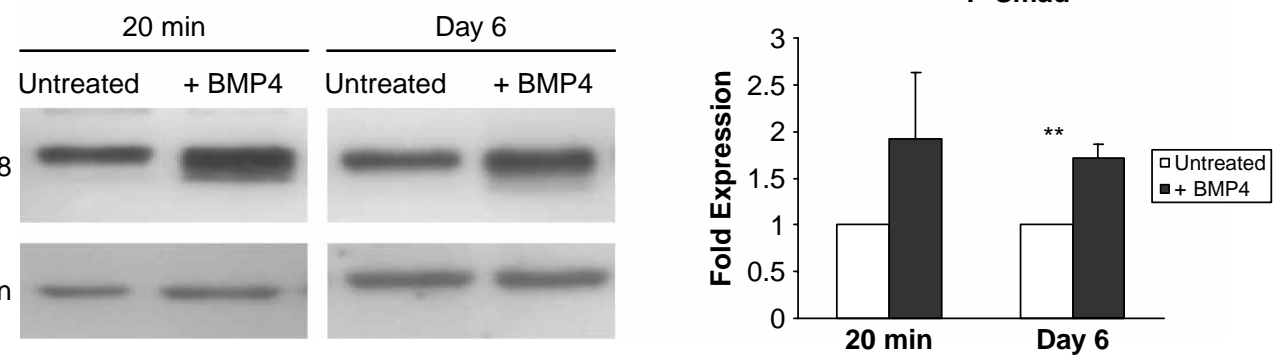

Figure 1. BMP4 activates BMP pathway in BEAS-2B cells. (a) Representative photomicrographs of phosphorylated-Smad1/5/8 in cells stimulated with BMP4 for $20 \mathrm{~min}$ and 6 days. Initial $20 \mathrm{~min}$ stimulus resulted in increased levels of phosphorylated-Smad1/5/8. After 6 days of culture, increased levels appeared sustained in BMP4-treated cells. Arrows indicate increased expression levels and/or nuclear translocation. Scale bars represent $50 \mu \mathrm{m}$. (b) Western blot analysis and corresponding densitometry quantification confirmed increased p-Smad levels in BMP4-treated cells. Bars represent the mean \pm SEM of three independent experiments. Students $t$ test was used to determine significance, ${ }^{\star \star} P<0.001$.
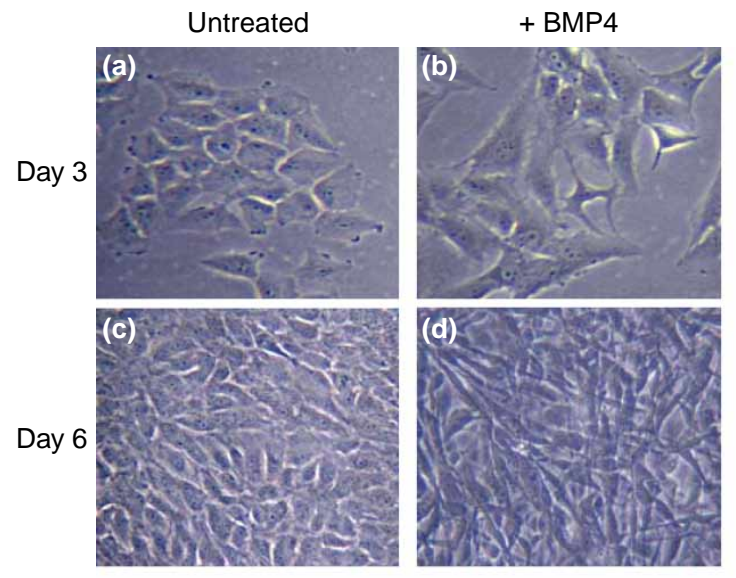

+ BMP4 - BMP4
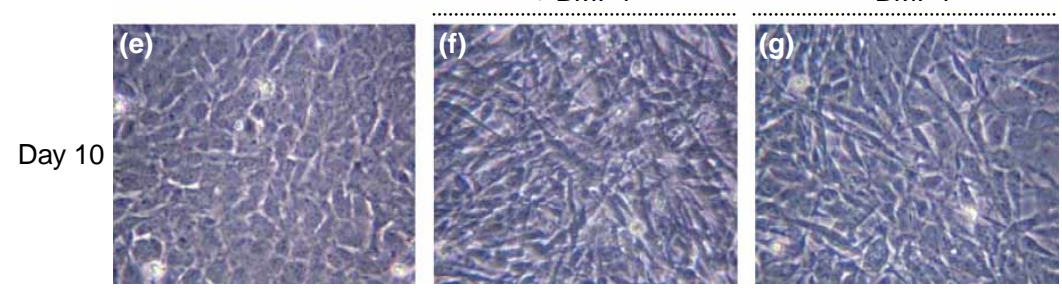

Figure 2. BMP4 induces a mesenchymal-like change in morphology. Phase contrast photomicrographs of BEAS-2B cells grown in serumfree medium (untreated) or in serum-free medium containing $100 \mathrm{ng} / \mathrm{ml} \mathrm{BMP} 4$ (+ BMP4) for 3 days (a and b) or 6 days (c and d). At day 3 , a change in morphology is apparent in the presence of BMP4 (b). At day 6, untreated cells display typical epithelial cell morphology (c). In contrast, BMP4-treated cells appear more fibroblast-like with loss of cell-cell contact (d). At day 6, cells were either left untreated or media was removed and replaced with either serum-free medium (-BMP) or serum-free media containing BMP4 ( + BMP4). Phase contrast images were obtained 4 days later. Untreated cells at day 10 retained an epithelial-like morphology (e). BMP4-treated cells which were re-stimulated at day 6 displayed an enhanced fibroblast-like morphology (f). Cells which had BMP4 withdrawn retained their fibroblast-like morphology (g) and appeared similar to their day 6 counterparts (d). 
to untreated cells. By day 6, BMP4-treated cell exhibited a spindle-shaped, fibroblast-like morphology (Figure 2d). When cells were re-fed with BMP4-containing medium at day 6 , the morphological effect was even more pronounced 4 days later at day 10 (Figure 2f). When BMP4-containing medium was replaced at day 6 with BMP4-free defined serumfree medium, the fibroblast morphology was still apparent at day 10 (Figure $2 \mathrm{~g}$ ). This indicates that the morphological effect is not 'scattering' which is normally reversed upon removal of the scatterinducing factor (Janda et al. 2002).

\section{Effects of BMP4 on proliferation and motility}

Given the marked effect of BMP4 on BEAS-2B cell morphology, we next examined proliferation and motility effects. After 6 days of culture, BMP4-induced a $48 \%$ decrease in BEAS-2B cell number compared to control medium (Figure 3a). The reduction in cell number was not due to BMP4-induced toxicity as an average of 5.7 and $4.1 \%$ non-viable cells were present in control and BMP4-stimulated populations, respectively ( $n=3$, data not shown).

A scrape assay was carried out to analyse BEAS-2B cell motility in a wounded monolayer in response to BMP4. Over a period of $17 \mathrm{~h}$, the wounded area remained largely unchanged in untreated monolayers (Figure $3 \mathrm{~b}$ and c). In contrast, in the same period, cells cultured in the presence of BMP4 migrated to refill the wounded area. It is unlikely that the area was repopulated by proliferating cells rather than migrating cells as proliferation was reduced in BMP4-treated cells compared to untreated controls (Figure 3a).

\section{BMP4 alters expression of adherens junction proteins in $B E A S-2 B$ cells}

Because morphology and motility were altered in BEAS-2B cells cultured with BMP4, we next investigated expression of epithelial-related adherens junction proteins and cytoskeletal proteins in BMP4treated cells. The expression of E-cadherin, $\alpha-, \beta-$ and $\gamma$-catenin and cytokeratins 8 and 18 was examined.

E-cadherin expression was almost completely abolished and was barely detectable by Western blot in BEAS-2B cells cultured with BMP4 (Figure 4). Expression of $\beta$ - and $\gamma$-catenin was also significantly reduced in response to $\mathrm{BMP} 4$. No change in expression levels of $\alpha$-catenin, cytokeratin 8 or 18 was detected in cells cultured with BMP4 at this time point.

\section{Expression of transcriptional regulators in BMP4-treated cells}

The morphological and phenotypic changes observed in BEAS-2B cells in response to BMP4 resemble an EMT. We therefore examined the expression of several
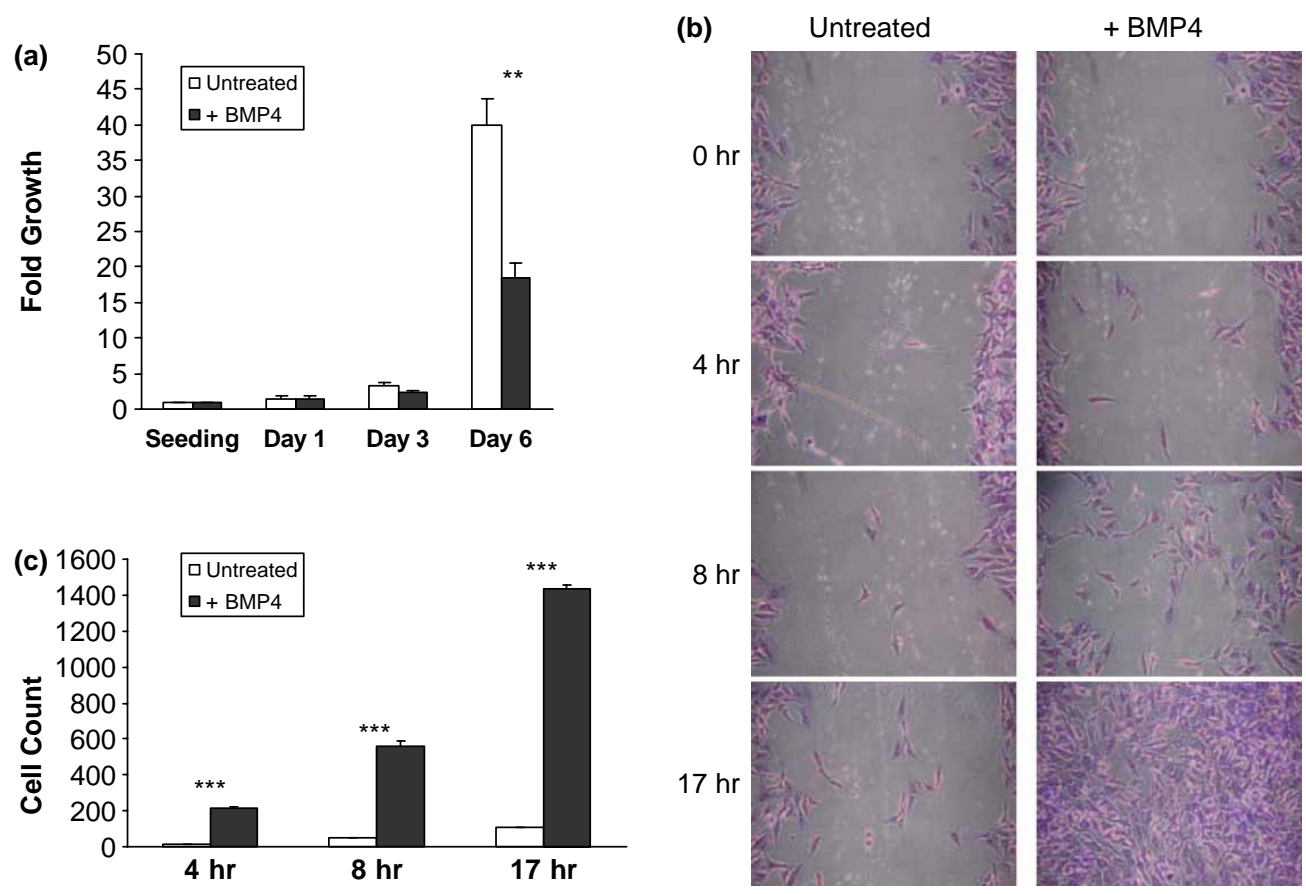

Figure 3. BMP4 modulates BEAS-2B cell proliferation and migration. (a) BMP4 significantly inhibited cell proliferation at day 6. Proliferation is presented as fold relative to the seeding density. Each bar represents the mean \pm SEM of three independent experiments. Significance as compared to untreated cells was obtained using the students $t$ test, $\star \star P<0.001$. (b) A wound assay was performed to assess the effect of BMP4 on cell migration. Cells in the presence of BMP4 began to migrate after $4 \mathrm{hr}$ and at $17 \mathrm{~h}$ the wounded area was entirely repopulated. (c) Graph illustrates number of cells migrated at each time point. Bars represent the mean \pm SEM of three independent experiments. Students $t$-test was used to determine significance, where ${ }^{\star \star \star} P<0.0001$. 


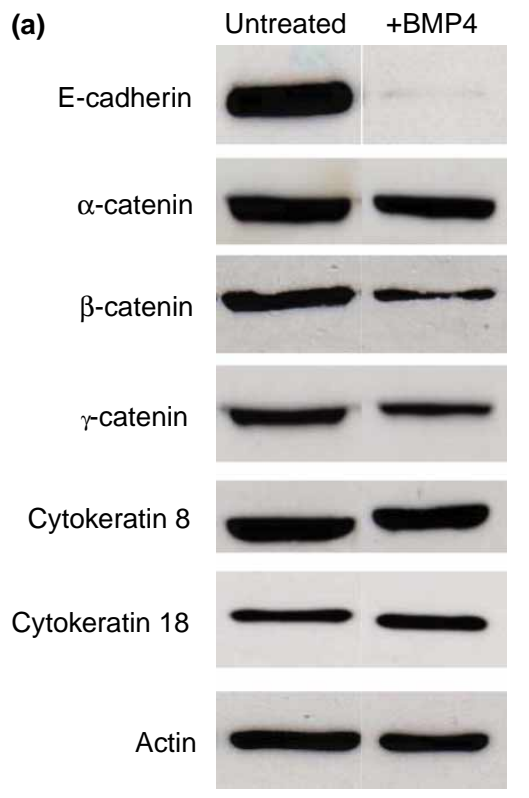

(b)

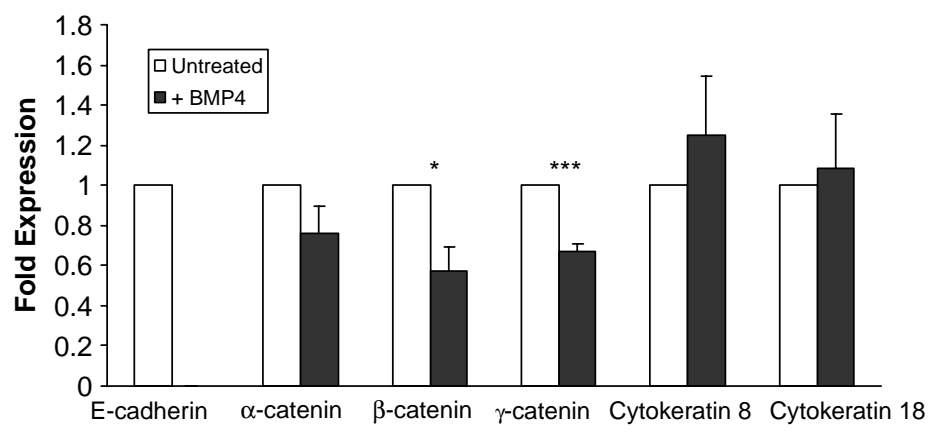

Figure 4. Expression of adherens junction proteins and cytokeratin proteins in BMP4-treated cells. (a) Western blot images of adherens junction and cytokeratin protein expression in untreated cells and cells cultured with BMP4 ( + BMP4) for 6 days. (b) Densitometric quantification presented as fold change compared to untreated cells. BMP4 treatment resulted in decreased expression of adherens proteins. No change in cytokeratin expression was detected. Values were normalised to actin. Each bar represents the mean \pm SEM of at least three independent experiments. Significance compared to untreated cells was obtained using the students $t$ test $\left({ }^{\star} P<0.05\right.$ and $\left.{ }^{\star \star \star} P<0.001\right)$.

transcriptional regulators which are known to either downregulate epithelial gene expression, induce mesenchymal gene expression, or both during EMT. The expression of Snai1, Snai2, Snai3, Zeb1, Zeb2 and Twist was consistently increased in BMP4-treated BEAS-2B cells at the day 6 time point (Figure 5).

\section{Altered expression of mesenchymal markers in response to BMP4}

The expression of several mesenchymal markers typically expressed in EMT was examined by semiquantitative PCR in BMP4-treated cells. Desmin and $\mathrm{N}$-cadherin gene expression was significantly increased in BEAS-2B cells in response to BMP4 (Figure 6). Expression of collagen $1 \mathrm{~A} 1$ and $1 \mathrm{~A} 2$, fibronectin and vimentin was also consistently increased while $\alpha$-smooth muscle actin appeared unchanged at day 6. Cytokeratin 18 expression was not changed at the mRNA level with BMP4 treatment.

\section{BMP4 modulates expression of extracellular matrix- related genes in $B E A S-2 B$ cells}

To gain further insight into the phenotype-induced by BMP4 treatment of BEAS-2B cells, PCR array plates were used to quantitatively analyse expression of a wide range of extracellular matrix (ECM)-related genes.

From a total of 84 ECM-related genes examined in BMP4-treated BEAS-2B cells, significant increases in expression of 13 genes (Table II) and significant decreases in expression of 12 genes (Table III) were detected. No significant changes were detected in expression levels of the remaining genes (Supplementary Table I). Cell adhesion molecules, ECM proteins and ECM-degrading enzymes were represented in both the upregulated and downregulated cohorts of genes. Expression of genes encoding tenascin C, tetranectin, thrombospondin 2, matrix metalloproteinase (MMP) 16 and vascular cell adhesion molecule (VCAM) were increased more than 5 -fold. In contrast, E-cadherin, collagen VI $\alpha 1$ and gelatinase A gene expression was reduced more than 6-fold.

Four genes from the PCR arrays were selected for verification by independent QPCR. $C D H 1$ (E-cadherin) and $M M P 2$ (gelatinase A) were selected as the two genes with the largest reduction in expression levels. COL5A1 (collagen V $\alpha 1$ ) and TGFBI (TGF- $\beta$ induced) were selected as genes with relatively modest increased levels of expression. QPCR was done using total RNA newly isolated from three independent passages of BEAS-2B cells and using alternative primers to those used in array experiments. Similar changes in gene expression were detected when COL5A1, TGFBI and $C D H 1$ were examined by QPCR compared with the PCR arrays (Figure 7). While, a reduction in $M M P 2$ expression was detected using QPCR, the extent of the reduction was less that that observed using PCR arrays.

\section{Discussion}

BMPs possess a wide range of biological activities that influence processes such as morphogenesis, proliferation, apoptosis and differentiation in several 


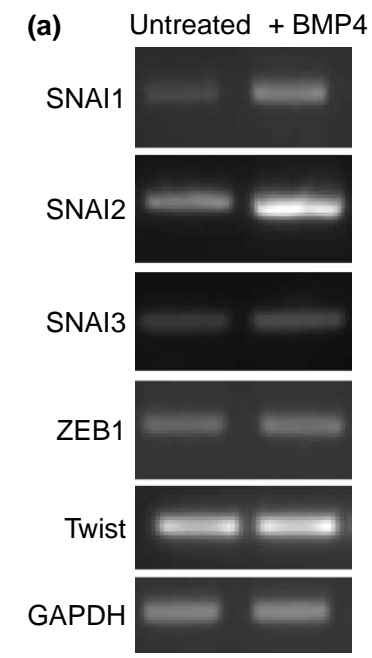

(b)

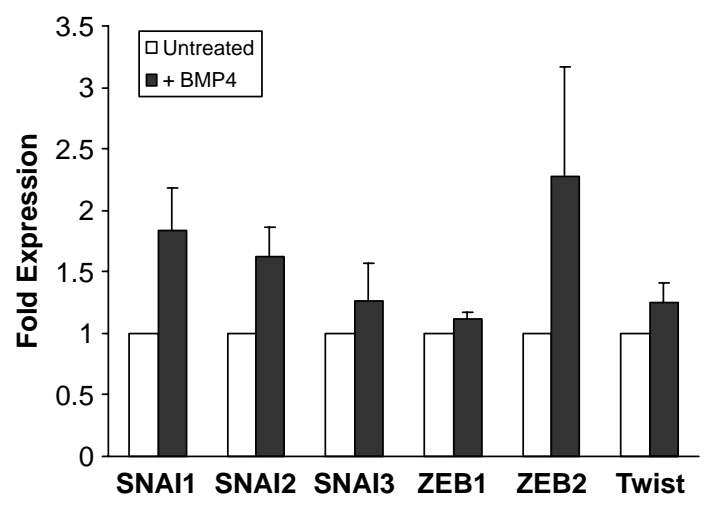

Figure 5. BMP4 modulates expression of transcription factors involved in EMT. (a) RT-PCR analysis demonstrates upregulation of several transcriptional regulators of E-cadherin gene expression at day 6 after BMP4 treatment. (b) Densitometric quantification was carried out and normalised to glyceraldehyde-3-phosphate (GAPDH). Real Time PCR data is presented for Zeb2. Data presented as fold change compared to untreated cells where bars represent the mean \pm SEM of three independent experiments. While genes were consistently upregulated following BMP4 treatment, no significance was obtained using the student's $t$-test.

cell types both during development and in adult tissues (Chen et al. 2004). BMP4 is essential during lung morphogenesis and regulates differentiation of airway epithelial cells within the developing lung bud (Bellusci et al. 1996). However, little is known regarding the role of BMPs in adult lungs. It has previously been reported that BMP4 induces senescence in A549 cells in vitro (Buckley et al. 2004). We found no evidence of senescence in BEAS-2B cells in response to BMP4 (data contained in Supplement). In the present study, we have demonstrated that BMP4 modulates proliferation, morphology and cell adhesion in BEAS-2B human bronchial epithelial cells in a manner consistent with EMT. BMP pathway activation and upregulation of BMP4 expression has been reported in allergen-induced inflammation in mouse lungs (Rosendahl et al. 2002). Our findings indicate that the role of BMP4 as a morphogen and
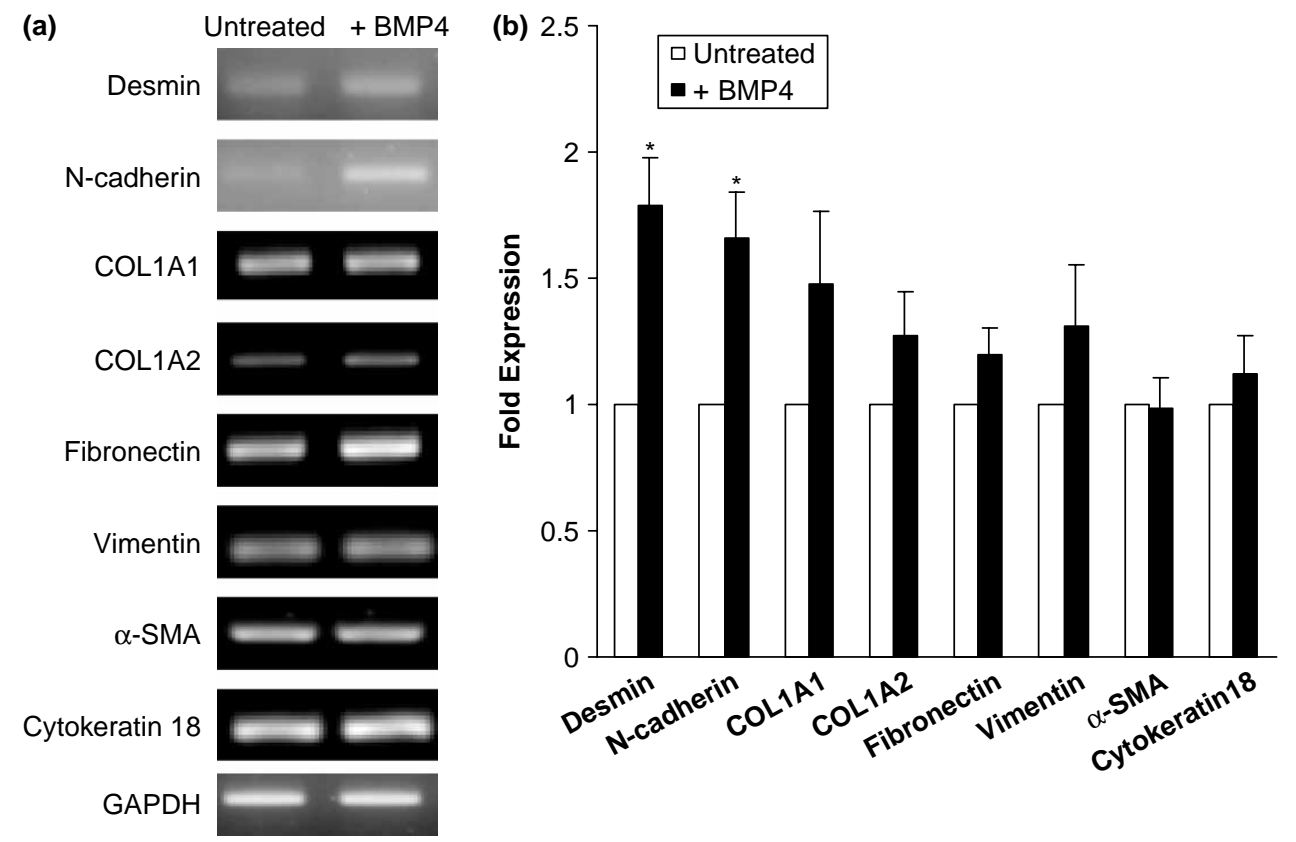

Figure 6. BMP4 modulates expression of cytoskeletal and ECM-related genes. (a) RT-PCR analysis of cytoskeletal and ECM-related gene expression following treatment with BMP4. (b) Densitometric quantification was carried out and normalised to glyceraldehyde-3-phosphate $(\mathrm{GAPDH})$. Data presented as fold change compared to control where bars represent the mean \pm SEM of three independent experiments. Significance compared to untreated cells was obtained using the student's $t$-test $\left({ }^{\star} P<0.05\right)$. 
Table II. Extracellular matrix-related genes upregulated by BMP4.

\begin{tabular}{|c|c|c|c|c|}
\hline Accession ID & Gene name & Symbol & $P$ value & BMP4/untreated \\
\hline NM_001078 & Vascular cell adhesion molecule 1 & VCAM1 & 0.0014 & 13.48 \\
\hline NM_003247 & Thrombospondin 2 & THBS2 & 0.0001 & 9.17 \\
\hline NM_003278 & C-type lectin domain family 3 , member B (tetranectin) & CLEC3B & 0.0007 & 8.82 \\
\hline NM_005941 & Matrix metallopeptidase 16 (membrane-inserted) & MMP16 & 0.0000 & 7.05 \\
\hline NM_002160 & Tenascin C (hexabrachion) & TNC & 0.0015 & 5.51 \\
\hline NM_001855 & Collagen, type XV, alpha 1 & COL15A1 & 0.0311 & 4.43 \\
\hline NM_002026 & Fibronectin 1 & FN1 & 0.0041 & 3.70 \\
\hline NM_021110 & Collagen, type XIV, alpha 1 & COL14A1 & 0.0010 & 3.10 \\
\hline NM_000093 & Collagen, type V, alpha 1 & COL5A1 & 0.0002 & 2.34 \\
\hline NM_000358 & Transforming growth factor, beta-induced, $68 \mathrm{kDa}$ & TGFBI & 0.0266 & 2.32 \\
\hline NM_000211 & Integrin, beta 2 & ITGB2 & 0.0045 & 2.02 \\
\hline NM_002423 & Matrix metallopeptidase 7 (matrilysin) & MMP7 & 0.0013 & 1.54 \\
\hline NM_004370 & Collagen, type XII, alpha 1 & COL12A1 & 0.0410 & 1.53 \\
\hline
\end{tabular}

Mean expression $\left(C_{\mathrm{t}}\right)$ values were calculated from $n=3$ arrays and fold difference between BMP4 and untreated cells was calculated as $2 \Delta \Delta C_{\mathrm{t}}$. Fold changes less than 1 are expressed as the negative inverse. $P$ values were calculated by Student's paired $t$-test with a two-tailed distribution and significance established at $P<0.05$.

inducer of EMT during development may be recapitulated in adult lungs during inflammatory and disease processes.

The detection of phosphorylated Smad 1/5/8 in BEAS-2B cells cultured in control defined serum-free medium for 6 days indicates autocrine BMP activity in these cells. We have confirmed that BEAS-2B cells express BMP4 mRNA as well as that of BMP2 and BMP7 (data not shown). Increased levels of phosphorylated Smads following addition of BMP4 indicates that the cells can respond specifically to this ligand.

Under the present conditions where cells were seeded at low densities, the induction of a mesenchymal-like morphology in BEAS-2B cells occurred 3 days after addition of BMP4. It was noted that the morphological change usually occurred only after cells had established cell-cell contact and formed colonies. The retention of this mesenchymal-like morphology following the removal of BMP4 indicates that the effect is not merely a scatter effect, which would be expected to revert upon removal of BMP4, but rather a more permanent change in cell phenotype consistent with an EMT. BMP4treated BEAS-2B cells also exhibited reduced proliferation and increased motility, both of which are also features of EMT.

The appearance of the fibroblast-like morphology and increased motility were associated with changes in expression of epithelial and mesenchymal markers. BMP4 induced almost complete abrogation of E-cadherin protein expression in BEAS-2B cells (Figure 4). The downregulation of E-cadherin protein expression was reflected at the mRNA level both in the PCR array study (Table III) and by QPCR (Figure 7). Functional loss of E-cadherin is a hallmark of EMT during both development and tumour progression (Larue and Bellacosa 2005). Upregulation of Snail, Snai2 and other transcriptional repressors in BEAS2B cells following BMP4 treatment indicates that similar activation of EMT-related signalling pathways occurs in adult lung cells in response to BMPs. Reduced E-cadherin expression was accompanied by significant downregulation of $\beta$ - and $\gamma$-catenin protein

Table III. Extracellular matrix-related genes downregulated by BMP4.

\begin{tabular}{|c|c|c|c|c|}
\hline Accession ID & Gene name & Symbol & $P$ value & BMP4/untreated \\
\hline NM_004530 & Matrix metallopeptidase 2 (gelatinase A) & MMP2 & 0.0001 & -31.96 \\
\hline NM_004360 & Cadherin 1 , type 1 , E-cadherin & CDH1 & 0.0001 & -15.15 \\
\hline NM_001848 & Collagen, type VI, alpha 1 & COL6A1 & 0.0011 & -6.45 \\
\hline NM_001523 & Hyaluronan synthase 1 & HAS1 & 0.0019 & -4.77 \\
\hline NM_007037 & ADAM metallopeptidase w/thrombospondin type 1 motif, 8 & ADAMTS8 & 0.0002 & -4.12 \\
\hline NM_001331 & Catenin (cadherin-associated protein), delta 1 & CTNND1 & 0.0458 & -3.20 \\
\hline NM_001849 & Collagen, type VI, alpha 2 & COL6A2 & 0.0116 & -2.42 \\
\hline NM_002291 & Laminin, beta 1 & LAMB1 & 0.0128 & -2.15 \\
\hline NM_139028 & ADAM metallopeptidase w/thrombospondin type 1 motif, 13 & ADAMTS13 & 0.0128 & -2.12 \\
\hline NM_001850 & Collagen, type VIII, alpha 1 & COL8A1 & 0.0146 & -2.06 \\
\hline NM_003255 & TIMP metallopeptidase inhibitor 2 & TIMP2 & 0.0129 & -1.61 \\
\hline NM_003119 & Spastic paraplegia 7 & SPG7 & 0.0470 & -1.56 \\
\hline
\end{tabular}

Mean expression $\left(C_{\mathrm{t}}\right)$ values were calculated from $n=3$ arrays and fold difference between BMP4 and untreated cells was calculated as $2 \Delta \Delta C_{\mathrm{t}}$. Fold changes less than 1 are expressed as the negative inverse. $P$ values were calculated by Student's paired $t$-test with a two-tailed distribution and significance established at $P<0.05$. 

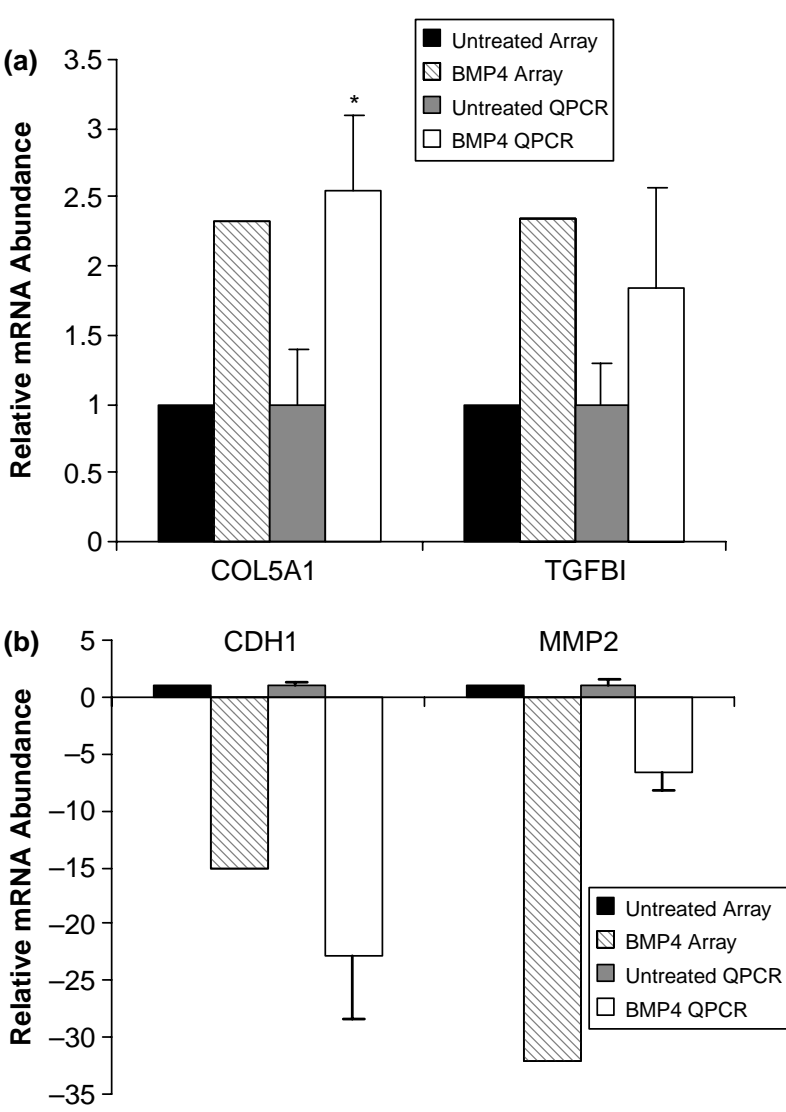

Figure 7. Comparison of the relative expression of two (a) upregulated and two (b) down-regulated genes identified by PCR array experiments and verified by independent quantitative polymerase chain reaction (QPCR). QPCR was done using total RNA isolated from three independent passages and using independent primers to those used in array experiments. Relative mRNA abundance was calculated using GAPDH as an endogenous control. QPCR values are mean \pm SEM of $n=3(\mathrm{CDH} 1: n=2)$ and normalised to the mean of untreated cells $\left({ }^{\star} P<0.05\right)$.

levels. Expression of these genes remained unchanged in the PCR array study (Supplementary Table I), however, suggesting possible post-translational regulation of these proteins in response to $\mathrm{BMP} 4$.

At the day 6 time point examined in this study, alterations in expression of several mesenchymal markers associated with EMTwere apparent in response to BMP4. Desmin and N-cadherin mRNA levels were significantly upregulated while collagens, fibronectin and vimentin were also consistently increased. A broader view of the phenotypic changes induced by BMP4 was obtained in the PCR array study which revealed changes in expression of genes encoding several ECM proteins and matrix degrading enzymes. In several cases, the identity of these genes and the directionality of their change were consistent with EMT. For example, increased expression of thrombospondin 2, tenascin C, fibronectin, MMP7, integrin $\beta 2$ and collagen genes has been reported in EMT, during either development or tumour progression, and sometimes both (Chagraoui et al. 2003; Maschler et al. 2004; Larue and Bellacosa 2005). Similarly, downregulation of E-cadherin and $\delta$-catenin gene expression seen from the PCR array (Table II) is consistent with EMT. However, several genes that were downregulated by BMP4 such as MMP2 and other matrix degrading enzymes, have previously been reported as upregulated during EMT (Larue and Bellacosa 2005). In addition, levels of cytokeratin 8 and 18 proteins would be expected to decline during EMT but were unchanged with BMP treatment. The process of EMT is not well defined in adult cells and it is unknown what, if any, gene expression profile represents this process. It is likely that this profile varies with cell type, microenvironment and specific time point within the EMT process. For example, during development, MMP2 is expressed while neural crest cells undergo EMT but is rapidly downregulated as they disperse (Duong and Erickson 2004). It is possible that different concentrations of $\mathrm{BMP} 4$, the presence of additional signals, or a longer exposure time would result in further EMT-related changes in BEAS-2B cells. Alternatively, the extent to which epithelial features are lost, and mesenchymal characteristics are acquired, varies during both developmental- and carcinogenesis-associated EMT, depending on cell type (Shook and Keller 2003). Therefore, complete loss of epithelial markers may never occur in BEAS-2B cells, regardless of signals encountered.

This study represents the first report of EMT-like changes in airway epithelial cells. EMT has been demonstrated in alveolar epithelial cells, both primary cells and cell lines, in response to TGF- $\beta$ (Willis and Borok 2007). It has been suggested that EMTof alveolar cells may contribute to fibrosis in vivo in diseases such as idiopathic pulmonary fibrosis. Although it is not known if BMPs are involved in EMT during lung morphogenesis, they are known to play a key role in EMT in other developing and adult tissue types. Our study indicates that this activity may be recapitulated in adult airways, possibly during inflammatory and remodelling processes in airway diseases such as asthma. Reduced E-cadherin expression alone could compromise epithelial barrier integrity and contribute to inflammation. Full EMT could result in increased numbers of fibroblasts in the airways and loss of epithelial functions. BMP-mediated EMT may thus be a mechanism for fibrosis in inflammatory airway diseases.

\section{Acknowledgements}

This research was funded by grants from Science Foundation Ireland, Higher Education Authority Ireland PRTLI 3 and European Union Framework Programme 6 Marie Curie Actions.

\section{References}

Abe E. 2006. Function of BMPs and BMP antagonists in adult bone. Ann N Y Acad Sci 1068:41-53. 
Attisano L, Wrana JL. 2000. Smads as transcriptional comodulators. Curr Opin Cell Biol 12:235-243.

Bellusci S, Henderson R, Winnier G, Oikawa T, Hogan BL. 1996. Evidence from normal expression and targeted misexpression that bone morphogenetic protein $(\mathrm{Bmp}-4)$ plays a role in mouse embryonic lung morphogenesis. Development 122:1693-1702.

Buckley S, Shi W, Driscoll B, Ferrario A, Anderson K, Warburton D. 2004. BMP4 signaling induces senescence and modulates the oncogenic phenotype of A549 lung adenocarcinoma cells. Am J Physiol Lung Cell Mol Physiol 286:L81-L86.

Burdsal CA, Alliegro MC, McClay DR. 1991. Tissue-specific, temperal changes in cell adhesion to echinonectin in the sea urchin embryo. Dev Biol 144:327-334.

Chagraoui J, Lepage-Noll A, Anjo A, Uzan G, Charbord P. 2003. Fetal liver stroma consists of cells in epithelial-to-mesenchymal transition. Blood 101:2973-2982.

Chen D, Zhao M, Harris SE, Mi Z. 2004. Signal transduction and biological functions of bone morphogenetic proteins. Front Biosci 9:349-358.

Duong TD, Erickson CA. 2004. MMP-2 plays an essential role in producing epithelial-mesenchymal transformations in the avian embryo. Dev Dyn 229:42-53.

Frontelo P, Leader JE, Yoo N, Potocki AC, Crawford M, Kulik M, Lechleider RJ. 2004. Suv39h histone methyltransferases interact with Smads and cooperate in BMP-induced repression. Oncogene 23:5242-5251.

Hamada S, Satoh K, Hirota M, Kimura K, Kanno A, Masamune A, Shimosegawa T. 2007. Bone morphogenetic protein 4 induces epithelial-mesenchymal transition through MSX2 induction on pancreatic cancer cell line. J Cell Physiol 213:768-774.

Herpin A, Cunningham C. 2007. Cross-talk between the bone morphogenetic protein pathway and other major signaling pathways results in tightly regulated cell-specific outcomes. Febs J 274:2977-2985.

Janda E, Lehmann K, Killisch I, Jechlinger M, Herzig $M$, Downward J, Beug H, Gruner S. 2002. Ras and TGF $\beta$ cooperatively regulate epithelial cell plasticity and metastasis: Dissection of Ras signaling pathways. J Cell Biol 156:299-313.

Kalluri R, Neilson EG. 2003. Epithelial-mesenchymal transition and its implications for fibrosis. J Clin Invest 112:1776-1784.

Langenfeld EM, Bojnowski J, Perone J, Langenfeld J. 2005. Expression of bone morphogenetic proteins in human lung carcinomas. Ann Thor Surg 80:1028-1032.

Larue L, Bellacosa A. 2005. Epithelial-mesenchymal transition in development and cancer: Role of phosphatidylinositol $3^{\prime}$ kinase/AKT pathways. Oncogene 24:7443-7454.

Lee ML, Shoukat D, Kalluri R, Thompson EW. 2006. The epithelial-mesechymal transition: New insights in signalling, development, and disease. J Cell Biol 172:973-981.

Maschler S, Grunert S, Danielopol A, Beug H, Wirl G. 2004. Enhanced tenascin-C expression and matrix deposition during Ras/TGF-beta-induced progression of mammary tumor cells. Oncogene 23:3622-3633.

Miyazono K, Maeda S, Imamura T. 2005. BMP receptor signaling: Transcriptional targets, regulation of signals, and signaling crosstalk. Cytokine Growth Factor Rev 16:251-263.

Montesano R. 2007. Bone morphogenetic protein-4 abrogates lumen formation by mammary epithelial cells and promotes invasive growth. Biochem Biophys Res Commun 353:817-822.

Nohe A, Hassel S, Ehrlich M, Neubauer F, Sebald W, Henis YI, Knaus P. 2002. The mode of bone morphogenetic protein
(BMP) receptor oligomerization determines different BMP-2 signaling pathways. J Biol Chem 277:5330-5338.

Okagawa H, Markwald RR, Sugi Y. 2007. Functional BMP receptor in endocardial cells is required in atrioventricular cushion mesenchymal cell formation in chick. Dev Biol 306:179-192.

Peinado H, Olmeda D, Cano A. 2007. Snail, Zeb and bHLH factors in tumour progression: An alliance against the epithelial phenotype? Nat Rev Cancer 7:415-428.

Perk J, Iavarone A, Benezra R. 2005. Id family of helix-loop-helix proteins in cancer. Nat Rev Cancer 5:603-614.

Reddel RR, Yang K, Gerwin BI, McMenamin MG, Lechner JF, Su RT, Brash DE, Park J-B, Rhim JS, Harris CC. 1988. Transformation of human bronchial epithelial cells by infection with SV40 or adenovirus-12 SV40 hybrid virus, or transfection via strontium phosphate coprecipitation with a plasmid containing SV40 early region genes. Cancer Res 48:1904-1909.

Rosendahl A, Pardali E, Speletas M, Ten Dijke P, Heldin CH, Sideras P. 2002. Activation of bone morphogenetic protein/Smad signaling in bronchial epithelial cells during airway inflammation. Am J Respir Cell Mol Biol 27:160-169.

Ruberte E, Marty T, Nellen D, Affolter M, Basler K. 1995. An absolute requirement for both the type II and type I receptors, punt and thick veins, for dpp signaling in vivo. Cell 80:889-897.

Sakai D, Suzuki T, Osumi N, Wakamatsu Y. 2006. Cooperative action of Sox9, Snail2 and PKA signalling in early neural crest development. Development 133:1323-1333.

Savanger P. 2001. Leaving the neighbourhood: Molecular mechanisms involved during epithelial-mesenchymal transition. Bioessays 23:912-923.

Shook D, Keller R. 2003. Mechanisms, mechanics and function of epithelial-mesenchymal transitions in early development. Mech Dev 120:1351-1383.

Simic P, Vukicevic S. 2005. Bone morphogenetic proteins in development and homeostasis of kidney. Cytokine Growth Factor Rev 16:299-308.

Theriault BL, Shepherd TG, Mujoomdar ML, Nachtigal MW. 2007. BMP4 induces EMT and Rho GTPase activation in human ovarian cancer cells. Carcinogenesis 28:1153-1162.

Thiery JP. 2003. Epithelial-mesenchymal transition in development and disease pathologies. Curr Opin Cell Biol 15:740-746.

Warburton D, Bellusci S. 2004. The molecular genetics of lung morphogenesis and injury repair. Paediatr Respir Rev 5:(Suppl A)S283-S287.

Weaver M, Yingling JM, Dunn NR, Bellusci S, Hogan BL. 1999. Bmp signaling regulates proximal-distal differentiation of endoderm in mouse lung development. Development 126:4005-4015.

Willis BC, Borok Z. 2007. TGF-beta-induced EMT: Mechanisms and implications for fibrotic lung disease. Am J Physiol Lung Cell Mol Physiol 293:L525-L534.

Winnier G, Blessing M, Labosky PA, Hogan BL. 1995. Bone morphogenetic protein- 4 is required for mesoderm formation and patterning in the mouse. Genes Dev 9:2105-2116.

Wozney JM. 1989. Bone morphogenetic proteins. Prog Growth Factor Res 1:267-280.

Wozney JM. 1992. The bone morphogenetic protein family and osteogenesis. Mol Reprod Dev 32:160-167.

Zavadil J, Bottinger EP. 2005. TGF- $\beta$ and epithelial-to-mesenchymal transitions. Oncogene 24:5764-5774.

Zhang C, Evans T. 1996. BMP-like signals are required after the midblastula transition for blood cell development. Dev Genet 18:267-278. 